\title{
Molecular identification and antibiotic resistance patterns of diverse bacteria associated with shrimp PL nurseries of Bangladesh: suspecting Acinetobacter venetianus as future threat
}

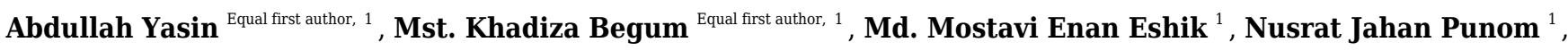 \\ Shawon Ahmmed ${ }^{1,2}$, Mohammad Shamsur Rahman ${ }^{\text {Corresp. } 1}$ \\ ${ }^{1}$ Aquatic Animal Health Group, Department of Fisheries, Faculty of Biological Sciences, University of Dhaka, Dhaka-1000, Bangladesh \\ 2 Brackishwater station, Bangladesh Fisheries Research Institute (BFRI), Khulna-9280, Bangladesh \\ Corresponding Author: Mohammad Shamsur Rahman \\ Email address: shamsur@du.ac.bd
}

Shrimp aquaculture has been accomplished with breeding and nursing of shrimp in an artificial environment to fulfill the increasing demand of shrimp consumption worldwide. However, the microbial diseases appear as a serious problem in this industry. The study was designed to identify the diverse bacteria from shrimp PL (post-larvae) nurseries and to profile antibiotic resistance patterns. The rearing water (raw seawater, treated and outlet water) and shrimp PL were collected from eight nurseries of south-west Bangladesh. Using selective agar plates, thirty representative isolates were selected for 16S rRNA gene sequencing, antibiotic susceptibility test and MAR index calculation. Representative isolates were identified as Aeromonas caviae, Pseudomonas monteilii, Shewanella algae, Vibrio alginolyticus, V. brasiliensis, V. natriegens, V. parahaemolyticus, V. shilonii, V. xuii, Zobellella denitrificans which are Gram-negative, and Bacillus licheniformis and B. pumilus which are Gram-positive. Notably, six strains identified as Acinetobacter venetianus might be a concern of risk for shrimp industry. The antibiotic resistance pattern reveals that the strain YW08-97 (identified as P. monteilii) was resistant to all twelve antibiotics. Ceftazidime was the most powerful antibiotic since most of the studied strains were sensitive against it. The six strains of $A$. venetianus showed multiple antibiotic resistance patterns. MAR index were ranged from 0.08 to 1.0, and values of 26 isolates were more than 0.2 which means prior high exposure to the antibiotics. From the present study, it can be concluded that shrimp PL nurseries in southern part of Bangladesh are getting contaminated with antibiotic resistant pathogenic bacteria. 


\section{Molecular identification and antibiotic resistance patterns of}

2 diverse bacteria associated with shrimp PL nurseries of

3 Bangladesh: suspecting Acinetobacter venetianus as future

\section{4 threat}

6 Abdullah Yasin ${ }^{1 \#}$, Mst. Khadiza Begum ${ }^{1 \#, ~ M d . ~ M o s t a v i ~ E n a n ~ E s h i k ~}{ }^{1}$, Nusrat Jahan Punom ${ }^{1}$, 7 Shawon Ahmmed ${ }^{1,2}$ and Mohammad Shamsur Rahman ${ }^{1 *}$

8

${ }^{1}$ Aquatic Animal Health Group, Department of Fisheries, Faculty of Biological Sciences, University of Dhaka, Dhaka-1000, Bangladesh

2Present address: Brackish water station, Bangladesh Fisheries Research Institute (BFRI), Khulna 9280, Bangladesh

Running page head: Bacterial diversity in shrimp PL nurseries

*Corresponding Author:

Mohammad Shamsur Rahman

Aquatic Animal Health Group, Department of Fisheries, Faculty of Biological Sciences, University of Dhaka, Dhaka-1000, Bangladesh

Email address: shamsur@du.ac.bd

Tel: +8801818314899 , Fax: +88029667222 (VC office)

ORCID: 0000-0001-8447-3275

\# Abdullah Yasin and Mst. Khadiza Begum contributed equally to the manuscript 


\section{Abstract}

Shrimp aquaculture has been accomplished with breeding and nursing of shrimp in an artificial environment to fulfill the increasing demand of shrimp consumption worldwide. However, the microbial diseases appear as a serious problem in this industry. The study was designed to identify the diverse bacteria from shrimp PL (post-larvae) nurseries and to profile antibiotic resistance patterns. The rearing water (raw seawater, treated and outlet water) and shrimp PL were collected from eight nurseries of south-west Bangladesh. Using selective agar plates, thirty representative isolates were selected for $16 \mathrm{~S}$ rRNA gene sequencing, antibiotic susceptibility test and MAR index calculation. Representative isolates were identified as Aeromonas caviae, Pseudomonas monteilii, Shewanella algae, Vibrio alginolyticus, V. brasiliensis, $V$. natriegens, $V$. parahaemolyticus, V. shilonii, V. xuii, Zobellella denitrificans which are Gram-negative, and Bacillus licheniformis and B. pumilus which are Gram-positive. Notably, six strains identified as Acinetobacter venetianus might be a concern of risk for shrimp industry. The antibiotic resistance pattern reveals that the strain YWO8-97 (identified as $P$. monteilii) was resistant to all twelve antibiotics. Ceftazidime was the most powerful antibiotic since most of the studied strains were sensitive against it. The six strains of $A$. venetianus showed multiple antibiotic resistance patterns. MAR index were ranged from 0.08 to 1.0 , and values of 26 isolates were more than 0.2 which means prior high exposure to the antibiotics. From the present study, it can be concluded that shrimp PL nurseries in southern part of Bangladesh are getting contaminated with antibiotic resistant pathogenic bacteria.

KEY WORDS: Shrimp, PL nurseries, bacterial diversity, Acinetobacter venetianus, MAR index 
46

47

\section{Introduction}

Over the past three decades, the shrimp culture in Asia has been increasing rapidly, and became a major global industry that serves the increasing consumer demand for seafood (FAO 2006).

Furthermore, this sector has been contributing significantly to socio-economic development in many poor coastal communities of developing countries (FAO 2006). In 2018-19, the total production of shrimp and prawn in Bangladesh was more than 239855 MT (metric ton), of which 30036 MT frozen shrimp was exported earning USD 347.54 million (DoF 2020). Frozen shrimp and prawn covers around $80 \%$ of the total fisheries export earning over the last decade. In fiscal year 2019-20, solely the tiger shrimp, Penaeus monodon contributed $67 \%$ to the total earning from exported shrimp and prawn (DoF 2020). The giant tiger shrimp is mainly cultured in the coastal districts of Bangladesh including Cox's Bazar, Chattogram, Khulna, Bagerhat, Satkhira and adjacent districts (Matin et al. 2016).

At the beginning, the shrimp farming industry of Bangladesh was dependent on the stocking of wild post-larvae (PL). With the intensification of shrimp farming, the demand of shrimp PL has been increased (Jannat et al. 2017). In early 2000s, after transportation from hatcheries the PL of $2-3 \mathrm{~cm}$ length were stocked directly into the shrimp ponds resulting in high mortality due to poor acclimatization and predation (Nuruzzaman 2006). To overcome the problem associated with the quality and survival rate of PL, some nurseries have been established by the local people of shrimp culture area viz. Khulna and Satkhira districts. According to the description of nursery technician, the hatchery-bred shrimp nauplii or zoea collected from Cox's Bazar are nurtured up to PL stage of several days in concrete tanks in well-designed confined area to meet the demand of shrimp farmers. The rearing water of shrimp PL nurseries is being collected from the sea, and being used after water filtration and disinfection. 
69 The shrimp industry is extremely vulnerable to viral and bacterial diseases (Karim et al.

70 2017).Although the vast majority of bacteria are beneficial, a few bacteria are pathogenic

71 containing virulent genes. The bacterial diseases like vibriosis and black shell disease introduce a

72 symbolic restraint on the viable shrimp production (Bachere et al. 1995). Bacterial species of

73 Vibrionaceae family viz. Photobacterium phosphorum, P. leiognathi, Vibrio fischeri, V. harveyi,

$74 V$. splendidus and V. vulnificus affect the hatcheries.Moreover, Monodon baculovirus (MBV),

75 external fouling organisms, $V$. harveyi, $V$. anguillarum, $V$. vulnificus are found in shrimp eggs,

76 PL, rearing tank water (treated water), marine water source (raw water) and feed (Artemia

77 nauplii and microcapsulated feed) (Vaseeharan \& Ramasamy 2003). Some of the Vibrio species

act as opportunistic pathogens or secondary intruders and they can cause total mortality of

cultured shrimp (Nash et al. 1992). The bacteria have been found in a commercial freshwater

prawn hatchery of Chennai, India are mainly Gram-negative and the species were Aeromonas

spp., Pseudomonas spp., Vibrio spp., whereas Bacillus spp., and non-spore formers (NSF) were

the main Gram-positive bacteria (Kennedy et al. 2006). Eleven species of Vibrio which cause

diseases have been recorded from the shrimp farming systems in Asia (Lavilla-Pitogo 1995). A

severe disease problem distresses the farmed black tiger shrimp in India caused by $V$.

alginolyticus and $V$. harveyi (Karunasagar et al. 1997). P. indicus has been infected by luminous

$V$. harveyi in the past, and so as $V$. splendidus affects the $P$. monodon culture (Prayitno \&

Latchford 1995). The presence of $V$. harveyi also distresses the health of P. monodon (Lavilla-

Pitogo \& de la Pena 1998). Early mortality syndrome (EMS) or acute hepatopancreatic necrosis disease (AHPND) caused by $V$. parahaemolyticus has been noticed in P. orientalis (Xu et al.

Vibrio viz., V. owensii, V. harveyi, $V$. campbellii and $V$. punensis containing toxin genes are 
92 also responsible for AHPND in shrimps (Kondo et al. 2015, Dong et al. 2017, Liu et al. 2018,

93 Restrepo et al. 2018, Muthukrishnan et al. 2019). Acinetobacter venetianus has been reported as

94 a potential pathogen of red leg disease of freshwater cultured whiteleg shrimp very recently in

95 China, and the genus Acinetobacter is causing serious problems associated with high mortality

96 rates in aquaculture (Huang et al. 2020). Still, there is lack of information on $A$. venetianus as a

97 pathogen in the world shrimp industry.

98 Thus, proper biosecurity measures should be applied to prevent the diseases in shrimp

99 aquaculture caused by several microorganisms. The implication of biosecurity in shrimp industry

100 defines the practice of specific pathogen exclusion from broodstock, hatcheries, grow out farms,

101 and from the entire area for disease anticipation (Lightner 2003). Although only three hatcheries

102 of Cox's Bazar and Khulna districts have been authorized in 2018-19 for the use of SPF

103 broodstock for PL production (DoF 2020), most of the hatcheries still use wild broodstock.

104 In addition, antimicrobial resistance (AMR) has become a potential danger to public health, and

105 the indiscriminate use of antibiotics in animals has been recognized as a major issue nowadays.

106 Different types of antibiotics and other antimicrobial agents are used in shrimp production,

107 predominantly in shrimp hatcheries of Bangladesh and elsewhere (Holmstrom et al. 2003, Uddin

108 \& Kader 2006, Thuy et al. 2011, Shamsuzzaman \& Biswas 2012, Ali et al. 2016, Chi et al. 2017,

109 Hinchliffe 2019).

110 Thus, the objective of this study was to identify diverse bacterial strains from the water and

111 shrimp PL samples from different nurseries of shrimp farming regions of Bangladesh. Moreover,

112 the antibiotic susceptibility and multiple antibiotic resistance profiles were also investigated for

113 the representative bacterial isolates.

114 Materials \& Methods 
115 Collection of water and post larvae (PL) samples from nurseries

116 To characterize the bacteria, shrimp PL and three kinds of water samples viz. raw seawater, 117 treated (after filtration and disinfection) water and outlet water were collected from eight

118 nurseries of south-west region of Bangladesh (five nurseries from Dacope Upazilla in Khulna 119 district and three from Satkhira Sadar Upazilla in Satkhira district; Fig. 1). The PL were picked

120 from water using scoop net and packed in a zipper bag with little amount of water, and after a 121 while those were dead. From each nursery, we collected about 200-300 PL, and used as pooled 122 samples. For three kinds of water samples, we took about $500 \mathrm{ml}$ of the water in the sterile bottles 123 from each nursery. All the samples were transferred in the sample box with ice (APHA 1998) 124 and finally brought to the laboratory for further analysis.

\section{Sample processing for bacterial culture}

126 PL samples were homogenized with physiological saline using sterile mortar-pestle at 1:9 ratios 127 and taken separately into sterile zipper bags. Then $100 \mu \mathrm{L}$ of each sample solution was taken with $900 \mu \mathrm{L}$ sterile physiological saline separately and diluted up to $10^{-5}$ fold to isolate different bacteria on TCBS (thiosulphate citrate bile salt), EMB (eosin methylene blue), SS (SalmonellaShigella), and MSA (mannitol salt agar) agar media. For the isolation of Vibrio spp. the processed samples were inoculated in alkaline peptone water (APW) and incubated for 6-18hrs at $37^{\circ} \mathrm{C}$ for enrichment.

\section{Isolation of diverse bacterial colonies from selective agar plates}

From diluted PL samples, raw water and outlet water samples, $100 \mu \mathrm{L}$ of $10^{-1}$ and $10^{-3}$ dilution were inoculated on sterile TCBS (Oxoid, UK), SS (Oxoid, UK), MSA (Oxoid, UK), and EMB

136 (Oxoid, UK) agar plates. Only from treated water, $100 \mu \mathrm{L}$ of processed undiluted water sample and $10^{-2}$ dilution sample was inoculated on different agar plates. Then, the samples were spread thoroughly by using a sterile glass spreader. The plates were transferred into an incubator at $37^{\circ} \mathrm{C}$ for $18-24 \mathrm{hrs}$. After incubation, the well discrete colonies from different plates were 
140 selected for subculture on TCBS, SS, MSA and EMB agar plates. Overall, 98 colonies were

141 selected primarily and sub-cultured on respective selective agar plates for isolated single

142 colonies. The selected colonies from respective agar plates were taken and streaked on the fresh

143 respective plates to get isolated single colony for pure culture. Based on the colony morphology

144 on selective agar plates, thirty representative isolates were cultured by streaking plate technique

145 on TSA plates for further works.

146 Molecular identification of the isolates

147 The heat extraction method was performed for the DNA extraction from 30 representative

148 bacterial isolates (Rahman et al. 2014). The target DNA amplicon was amplified using universal

149 primers for 16S rRNA gene: 27F 5 -AGAGTTTGATCCTGGCTCAG-3 $\square$ and 1492R 5 -

150 CGGTTACCTTGTTACGACTT-3 (Weisburg et al. 1991). The polymerase chain reaction

151 (PCR) was done following the reaction mixture and thermal cycling condition as described by

152 Punom et al. (2016). The amplified products were checked for the desired amplicon in 1\%

153 agarose gel. The amplified DNA was further purified with the Wizard SV Gel and PCR Clean-

154 Up System (Promega, USA) according to the manufacturer instructions prior to sequencing. The

155 sequencing of thirty PCR products was performed using the BigDye Terminator v 3.1 Cycle

156 sequencing Kit (Applied Biosystems, USA) according to the manufacturer instructions and

157 capillary electrophoresis was done using the ABI Genetic Analyzer (Applied Biosystems, USA).

158 To view the DNA sequences, the Geospizas Finch TV version 1.4 was used. BLAST (Basic

159 Local Alignment Search Tool) was used for comparing primary sequence information.

160 A neighbor-joining phylogenetic tree was constructed using MEGA X software (Kumar et al.

161 2018) for the comparative analysis of $16 \mathrm{~S}$ rRNA sequences of the bacterial isolates of the present

162 study and the reference sequences deposited in the NCBI database. The tree was drawn to scale, 
163 with branch lengths in the same units as those of the evolutionary distances used to infer the

164 phylogenetic tree. The evolutionary distances among these representative isolates were computed

165 using the maximum composite likelihood method.

\section{Antibiotic susceptibility test}

167 The Kirby-Bauer disc diffusion technique (Bauer et al. 1966) was performed to determine the 168 sensitivity or resistance of the isolates against 12 commonly available antibacterial compounds.

169 These were Ampicillin $(10 \mu \mathrm{g})$, Azithromycine $(15 \mu \mathrm{g})$, Chloramphenicol $(30 \mu \mathrm{g})$,

170 Ciprofloxacine $(5 \mu \mathrm{g})$, Ceftriaxone $(30 \mu \mathrm{g})$, Erythromycine $(15 \mu \mathrm{g})$, Gentamycin $(10 \mu \mathrm{g})$,

171 Sulphamethoxazole-Trimethoprime $(25 \mu \mathrm{g})$, Trimethoprime $(5 \mu \mathrm{g})$, Penicillin $\mathrm{G}(10 \mu \mathrm{g})$,

172 Tetracycline $(30 \mu \mathrm{g})$ and Ceftazidime $(30 \mu \mathrm{g})$.

173 Thirty representative isolates were inoculated in Mueller-Hinton Broth (MHB) (Oxoid, UK) and

174 incubated for 24 hours and then the broth culture was spread on the surface of the Mueller-

175 Hinton Agar (MHA). The antibiotic discs (Oxoid, UK) were applied on the surface of the agar

176 plates and incubated for 24 hours at $37^{\circ} \mathrm{C}$. Finally, the zone of inhibition was measured to detect

177 susceptibility of the bacteria (CLSI 2013).

178 Multiple antibiotic resistance (MAR) index of the studied isolates

179 The multidrug resistance and MAR index of the representative isolates were calculated against

180 twelve antibiotics. The bacterial strains resistant against three or more antibiotics were

181 considered as multidrug resistant strains (Schwarz et al. 2010). The MAR index values of the

182 bacterial isolates were calculated as: $a / b$; where ' $a$ ' represents the number of antibiotics the strain

183 was resistant to, and ' $b$ ' denotes the total number of antibiotics the strain was tested

184 (Krumperman 1983).

\section{RESULTS}




\section{Colony morphology of the representative bacterial isolates}

187 A total of thirty representative isolates were selected from four selective agar plates for further

188 study on the basis of different colors and sizes. The colony morphologies of representative

189 isolates are presented in Table 1.

\section{Molecular identification of the representative isolates}

191 Based on the colony morphology, 30 representative bacterial isolates were selected for 16S

192 rRNA gene sequencing in the present study. After amplification, all the representative isolates

193 showed positive band estimated at $1500 \mathrm{bp}$ in gel electrophoresis (Fig. 2). After sequencing, the 194 identification of $16 \mathrm{~S}$ rRNA gene sequences of the representative isolates by nucleotide BLAST

of NCBI is described in Table 2. Among the isolates from eight nurseries, 15 isolates showed

their identity with different strains of Vibrio spp. deposited in the NCBI database. YPL1-2

showed 100\% identity with V. xuii strain DSM 17185. The isolates YPL1-4, YWO1-14, YPL2-

19 and YPL4-52 revealed their similarity with $V$. shilonii strain having 100\% query coverage and identity. YPL2-16 showed 100\% identity and query cover with $V$. natriegens. The $16 \mathrm{~S}$ rRNA gene sequence of YPL-18 was identified as $V$. parahaemolyticus. After searching the sequences

in the GenBank, six isolates (YPL2-20, YWO3-27, YWO3-29, YWT6-68, YWO6-72 and

identity more than $99 \%$ with $V$. brasiliensis. On the other hand, 15 remaining isolates showed licheniformis and B. pumilus, respectively. These two isolates are Gram-positive.

Besides, the isolates YPL3-35, YWT4-39, YPL6-75, YWR7-79, YWO7-86 and YWR8-91 
209 75, which was isolated from SS agar plate showing cream colored small size colony. The isolates

210 YWO5-61 and YPL5-62 were identified as Zobellella denitrificans and Aeromonas caviae,

211 respectively. The sequences of YPL5-64, YPL7-89 and YWT8-94 showed 100\% query cover

212 and identity with Shewanella algae. The sequence of YWO8-97 reflects 100\% identity and query

213 cover with Pseudomonas monteilii, and YPL8-98 (not in full length due to noise in

214 chromatogram; only 630bp were used for blast search) showed similarity with Pseudomonas spp.

215 in the NCBI database.

216 The reported sequences in this study have been deposited in the NCBI GenBank database under

217 accession numbers from MT368010 to MT368038.

218 Phylogeny analysis

219 The phylogenetic tree was constructed based on the neighbor-joining method using the $16 \mathrm{~S}$

220 rRNA gene sequences of 29 representative isolates (YPL8-98 was excluded because of relatively

221 short sequence), and other reference sequences downloaded from the GenBank (Fig. 3). The tree

222 showed the taxonomic status of the studied 29 bacterial isolates through comparing their $16 \mathrm{~S}$

223 rRNA gene sequences with the other homologous sequences.

224 The identified bacterial strains have been summarized in the Table 3 according to the sample

225 types (water and shrimp PL) collected from shrimp PL nurseries.

226 Antibiotic susceptibility pattern of studied isolates

227 Table 4 shows antibiotic susceptibility pattern of 30 representative bacterial isolates. Among the

228 studied isolates, 26 bacterial strains were resistant to three or more antibiotics. The study found a

229 very remarkable isolate (YWO8-97; identified as $P$. monteilii) from outlet water of one nursery

230 of Satkhira district that was resistant to all 12 antibiotics. On the other hand, $V$. shilonii, $V$.

231 brasiliensis, B. licheniformis, $V$. natriegens, $V$. parahaemolyticus, B. pumilus, Z. denitrificans

Peer] reviewing PDF | (2021:07:64200:2:0:NEW 11 Dec 2021) 
232 were quite sensitive to the tested antibiotics. In this study, among six isolates identified as $V$.

233 alginolyticus, five isolates were resistant to ampicillin and gentamycin. All isolates of $V$.

234 alginolyticus were resistant to penicillin. Fig. 4 illustrates the percentage of the isolates showing

235 different types of susceptibility pattern against the tested antibiotics. No isolates were sensitive to

236 tetracycline except $V$. xuii (Fig. 4). Against 12 antibiotics, the resistant pattern of 30 studied

237 isolates was as: $\mathrm{P}>\mathrm{E}=\mathrm{W}>\mathrm{TE}>\mathrm{AMP}=\mathrm{CN}=\mathrm{SXT}>\mathrm{CIP}>\mathrm{AZM}=\mathrm{C}>\mathrm{CAZ}>\mathrm{CRO}$. Only ceftazidime

238 was the most effective antibiotic because $83.3 \%$ of the studied isolates was sensitive against it

239 (Fig. 4). The isolates identified as $A$. venetianus showed more resistance pattern as well as $S$.

240 algae. The six isolates identified as $A$. venetianus were resistant to penicillin $\mathrm{G}$, trimethoprim,

241 tetracycline, and consecutively five isolates were resistant to azithromycin, ciprofloxacin and

242 erythromycin. However, no isolate showed resistance against ceftazidime and gentamycin (Fig.

$2435)$.

244 Multiple antibiotic resistance (MAR) index of the studied isolates

245 Among 30 representative isolates, MAR index values were ranged from 0.08 to 1.0 and values

246 were $>0.2$ in 26 bacterial strains which means previous high exposure to the antibiotics and

247 thereby causing risk of antibiotic resistance (Fig. 6). Therefore, 86.7\% isolates were multidrug

248 resistant including all the six isolates identified as $A$. venetianus having MAR index from 0.5 to

249 0.75. The studied 14 bacterial strains identified as Vibrio spp. had MAR index from 0.08 to 0.67.

250 The strain YWO8-97 (P. monteilii) had the highest MAR index since the strain was resistant to

251 all tested antibiotics (Fig. 6).

252 DISCUSSION

253 Identification of diverse bacteria associated with shrimp PL nurseries 
254 The present study found Vibrio to be the dominant group of bacteria in the shrimp PL nurseries.

255 It has been revealed that bacterial species belong to the genus Vibrio are part of the natural flora

256 of penaeid shrimps (Gomez-Gil et al. 1998). Vibrio spp. can turn pathogenic, and they can be the

257 causal agents of shrimp mortality in the culture system eventually (Nash et al. 1992). Among

258 fifteen identified species of the genus Vibrio in the present study, six isolates were $V$.

259 alginolyticus. V. alginolyticus causes vibriosis disease in juvenile penaeid shrimp (Selvin \&

260 Lipton 2003). This bacterium has been reported to be isolated from diseased shrimp (Litopenaeus

261 vannamei) of culture ponds in Taiwan (Liu et al. 2004). In 2019, different shrimp farms of

262 Satkhira district of Bangladesh were suspected to be affected by vibriosis diseases, and

263 phenotypic characterization and 16S rRNA gene sequencing revealed $V$. alginolyticus as the

264 causative agent (Hannan et al. 2019). The challenge test for pathogenicity observation found that

265 the identified $V$. alginolyticus caused disease signs in juvenile shrimps and caused high mortality

266 (Hannan et al. 2019). Moreover, one of our studied strains was identified as $V$.

267 parahaemolyticus. $V$. parahaemolyticus and other Vibrio spp. carrying pirA and pirB toxin genes

268 in their plasmid are responsible for shrimp disease known as early mortality syndrome/acute

269 hepatopancreatic necrosis disease (EMS/AHPND) in cultured shrimp (Dong et al. 2017, Liu et

270 al. 2018, Restrepo et al. 2018, Muthukrishnan et al. 2019) and it caused large scale losses in

271 production of shrimp in Vietnam, China, Malaysia and Thailand (FAO 2013). AHPND positive

272 . parahaemolyticus strain in shrimp farms of Bangladesh have been reported in the past years

273 (Eshik et al. 2017, Eshik et al. 2018). On the other hand, the present study revealed four strains

274 of $V$. shilonii. Monoclonal antibody test, biochemical tests and 16S rRNA gene sequencing

275 reveals twelve strains of Vibrio spp. isolated from shrimp as $V$. shilonii (Longyant et al. 2008).

276 Moreover, in the present study the vibrios identified as $V$. xuii and $V$. brasiliensis which were 
277 first isolated and described from the marine aquaculture environment (Thompson et al. 2003).

278 The pathogenicity study on Vibrio spp. to rainbow trout (Oncorhynchus mykiss) and Artemia

279 nauplii disclosed that $V$. brasiliensis can cause mortality up to $100 \%$ (Austin et al. 2005). In

280 China, V. brasiliensis was reported to be characterized from moribund cultured Pacific white

281 shrimp in 2021 based on the phylogenetic analysis of 16S rRNA gene and some housekeeping

282 genes, and the researcher reported $V$. brasiliensis as a novel shrimp pathogen (Li et al. 2021). In

283 contrast, $V$. natriegens is known as one of the fastest growing nonpathogenic bacteria and a

284 potential organism for many biotechnological researches (Failmezger et al. 2018). Bacterial

285 strains isolated from marine soil sediments in Kerala, India have been identified as V. natriegens

286 through 16S rRNA gene sequencing and the bacterium has the potential as glycolipid

287 biosurfactant which is antipathogenic against $V$. harveyi to control vibriosis (Kannan et al. 2019).

288 Therefore, the Vibrio spp. identified from water samples, and shrimp PL samples collected from

289 nurseries in the present study support the findings of the previous studies mentioned. The

290 presence of pathogenic vibrios in PL nurseries can be critical since it may transmit to the shrimp

291 rearing farms, and cause disease when the environmental parameters are in favor of the

292 pathogenic agents.

293 Our study also found six isolates of $A$. venetianus from tiger shrimp (P. monodon) PL nurseries

294 of Khulna and Satkhira districts of Bangladesh. A. venetianus is a novel species which was

295 isolated from the sea in Japan, seawater in Israel, oil in Italy and aquaculture ponds in Denmark

296 (Vaneechoutte et al. 2009). In China, the red leg disease incidents occurred in almost entire

297 shrimp farming regions of Qingpu, Shanghai in 2017, and as a causative agent $A$. venetianus was

298 confirmed (Huang et al. 2020). They stated this as the first report of $A$. venetianus as a potential

299 pathogen of whiteleg shrimp (L. vannamei) cultured in freshwater (Huang et al. 2020). 
300 Additionally, the genus Acinetobacter is a potential pathogen in aquaculture which has caused

301 large mortalities in last few years in common carp, channel catfish, Indian major carp, blunt

302 snout bream and silver carp (Kozinska et al. 2014, Cao et al. 2016, Behera et al. 2017, Cao et al.

303 2017, Malick et al. 2020). To our knowledge, the finding of the present study is the first report

304 regarding the presence of $A$. venetianus in $P$. monodon PL nurseries of Bangladesh through $16 \mathrm{~S}$

305 rRNA gene sequencing. The present study found the presence of this pathogen in the raw sea

306 water, treated water, outlet water, and PL samples of five different nurseries. Therefore, it is a

307 matter of fear regarding A. venetianus presence in the shrimp farms of Bangladesh, although it

308 can be considered as an emerging issue to conduct more research.

309 In our study, three isolates of $S$. algae were identified. This is a rod-shaped marine bacterium

310 which has been isolated from seawater in previous study (Holt et al. 2005). S. algae has been

311 reported as human pathogen (Satomi 2014, Yousfi et al. 2017). S. algae can also act as an

312 opportunistic pathogen in aquatic animals and in China and Taiwan this bacterium caused

313 abalone mortalities (Cai et al. 2006) and ulcerative disease in marine fish, channel bass (Chang et

314 al. 2003). Therefore, it is not uncertain to find $S$. algae in shrimp nursery as the present study

315 investigated.

316 The present study found one strain of $Z$. denitrificans from outlet water of a shrimp nursery. This

317 is a denitrifying, heterotrophic and anaerobic bacterium. Z. denitrificans has been previously

318 isolated from the sediments of estuarine mangrove environment in Taiwan along with $Z$.

319 taiwanensis, both have been identified as novel species under a new genus Zobellella (Lin \&

320 Shieh, 2006). The genome of $Z$. denitrificans (ZD1) is characterized with a four-gene-cluster for

321 which the bacterium can effectively synthesize biodegradable polyhydroxybutyrate (PHB, an

322 alternative to plastics) in salty environment (Wu et al. 2019). The reason behind the presence of 
323 Z. denitrificans in outlet water of PL nursery might be due to the contact of nursery outlet water

324 with the sediment outside which may get salty. There is no report for any infectious incidence

325 due to this bacterial strain.

326 One strain of A. caviae was identified in the present study. From imported shrimp, a study found

327 sixty-three nalidixic acid-resistant Aeromonas spp., and phylogenetic analysis of gyr B sequences

328 indicated that among those 26 strains were A. caviae harboring toxin genes (Shakir et al. 2012).

329 In a study of marine shrimp species cultured in low salinity inland ponds, among 87 isolates of

330 Aeromonas spp., 7\% isolates are A. caviae (Yano et al. 2015).

331 In the present study, two isolates were identified as Pseudomonas spp. In a study of the

332 Phillippines, 40 bacterial isolates have been differentiated from the tiger shrimp eggs, larvae, PL,

333 the feeds, and the rearing water, and the study observed that the Vibrio spp. are dominant group.

334 Moreover, Vibrio and Pseudomonas spp. were reported to be present in both larvae and rearing

335 water (Torres 2007). Our investigation also found several Vibrio spp. and Pseudomonas spp.

336 from water and PL samples of shrimp nurseries. In Austria, a total of 520 Pseudomonas isolates

337 from different sampling sites of the Danube River have been isolated, and among those, the most

338 of the isolates were P. putida and P. fluorescens (Kittinger et al. 2016). One isolate in our study

339 was identified as $P$. monteilii. In China, $P$. monteilii strains have been isolated from soil samples

340 and identified through $16 \mathrm{~S}$ rRNA gene sequencing, and it has been suggested through

341 experiment that this particular strain could be useful for bioremediation of contaminated water

342 and soil through the degradation of pyrene (Ping et al. 2017). P. monteilii has been isolated from

343 the gut of grass carp and had the antibacterial activity against $A$. hydrophila (Qi et al. 2020). The

344 previous studies suggest that $P$. monteilii can be beneficial for the environment. 
345 The present study revealed the presence of two Gram-positive bacterial isolates viz. B.

346 licheniformis and B. pumilus in shrimp PL nurseries. B. licheniformis is found in plant and soil

347 (Veith et al., 2004), and used industrially for manufacturing biochemicals, enzymes, antibiotics,

348 and aminopeptidase (Rey et al. 2004). One of the most common probiotic groups is Bacillus spp.

349 that is used in aquaculture (Nayak 2021). The growth and survival of shrimp PL without water

350 exchange using marine B. pumilus and periphytic microalgae complex is effective in maintaining

351 low levels of total ammonia-nitrogen (TAN) and nitrite-nitrogen $\left(\mathrm{NO}_{2}-\mathrm{N}\right)$, therefore no

352 requirement to change the culture water (Banerjee et al. 2010). This complex of bacteria and

353 microalgae also has the potential to increase the PL survival, produce improved quality of

354 shrimp, reduce Vibrio counts and therefore, make simpler the larval culture system (Banerjee et

355 al. 2010). In our study, we found B. licheniformis and B. pumilus from raw and outlet water,

356 respectively that could have potential to maintain water quality in PL nurseries and probiotic

357 functions.

358 Antibiotic susceptibility pattern and MAR index of studied bacterial strains

359 In the present study, all 30 bacterial strains isolated from the raw sea water samples, treated

360 water, outlet water and PL samples showed multiple antibiotic susceptibility patterns against 12

361 different antibiotics (Table 4). The present study found that 26 bacterial strains isolated from

362 shrimp PL nurseries were resistant to three or more antibiotics. This is an indication how

363 antibiotics are being indiscriminately used in the shrimp farms and pose health risk to shrimp and

364 humans by promoting emergence of multidrug-resistant bacterial strains.

365 The antimicrobial resistance of Vibrio spp. isolated from marine whiteleg shrimp farms have a

366 high prevalence of resistance to ampicillin (45.2\%) and the tetracycline class $(38.7 \%)$; same

367 study revealed that multidrug resistance was associated with $29 \%$ of Vibrio isolates (Reboucas et 
368 al. 2011). $V$. alginolyticus isolates from oysters in Korea have been identified as resistant to

369 erythromycin and $73.3 \%$ was resistant to rifampin (Kang et al. 2016).

370 The previous studies suggested beneficial effects of $P$. monteilii, and this bacterium have anti-

371 pathogenic effect (Ping et al. 2017, Qi et al. 2020), however the strain identified in our study was

372 resistant to all the tested antibiotic which express high risk of antibiotic usage. On the other hand,

373 the present study identified three strains as $S$. algae and observed that all the strains were

374 susceptible to azithromycin, ceftriaxone and ceftazidime. Most of the Shewanella spp. were

375 reported to be susceptible to gentamicin (99\%), cefotaxmine (95\%), ciprofloxacin (94\%),

376 piperacillin and tazobactam (98\%) (Vignier et al. 2013). However, the present study found three

377 strains that were resistant to six or more antibiotics.

378 In the present study, 16S rRNA sequencing revealed the presence of $A$. venetianus in the shrimp

379 PL nurseries of southwest regions of Bangladesh. In China whiteleg shrimp, P. vannamei has

380 been reported to be affected recently by $A$. venetianus causing red leg disease and the strain

381 showed resistances to different antibiotics with multiple resistances against chloramphenicol,

382 quinolones and tetracyclines (Huang et al. 2020). The strains of the present study also showed

383 multiple antibiotic resistance and high resistance prevalence against penicillin $\mathrm{G}$, trimethoprim,

384 tetracycline, azithromycin, ciprofloxacin and erythromycin.

385 MAR index values $\geq 0.2$ indicates that the bacterial strains were previously exposed to heavy

386 antibacterial contamination, and therefore, are at high risk of multi-drug resistance (Noorlis et al.

387 2011, Nurhafizah et al. 2021). The present study found that most of the isolates were resistant to

388 three or more antibiotics having MAR index more than 0.2 including 14 Vibrio spp. and six $A$.

389 venetianus. In a study of Ecuadorian P. vannamei hatcheries, 20 bacterial strains were isolated

390 from shrimp larvae samples during mortality occurrences and the strains showed similarity to the 
391 Vibrio sequences as pathogens of the Harveyi clade through the $16 \mathrm{~S}$ rRNA sequence analysis

392 (Sotomayor et al. 2019). Those strains had MAR index ranged from 0.18 to 0.36 (average 0.23 )

393 and all the isolates were resistant to penicillin (Sotomayor et al. 2019). Our study also found that

394 most of the studied bacterial strains (68.7\%) were resistant to penicillin. Nurhafizah et al. (2021)

395 identified three strains of multidrug-resistant $V$. harveyi associated with luminescent vibriosis in

396 P. vannamei having MAR index of 0.4. Different species of the genus Vibrio from P. monodon

397 farms of Bangladesh showed multiple antibiotic resistance (Rahman et al. 2020). However, in

398 recent times, antimicrobial resistance has come under the spotlight as the COVID-19 crisis is

399 badly affecting almost the whole world because there are reports of antibiotic usage while

400 treating COVID-19 to avoid any secondary bacterial infections (Murray 2020). Antimicrobial

401 resistance causes about 700,000 deaths per year and it could be deadlier over the time as the

402 prediction indicates that the fatality may rise to 10 million by 2050

403 (https://foreignpolicy.com/2020/05/21/china-farms-antibiotic-resistance-antimicrobial-amr/).

404 Therefore, the antimicrobial resistance emerges as a global threat, and to fight this battle the

405 World Health Organization (WHO) launched a Global Action Plan (GAP) based on a 'One

406 Health' approach which highlights the interdependence of human health, animal health and the

407 environment (WHO 2015).

408 Conclusions

409 This study concludes the presence of both nonpathogenic and potentially pathogenic bacteria in

410 shrimp PL and water samples collected from the nurseries of south-west region of Bangladesh.

411 Specifically, there were some bacteria which have been proved in other studies as human

412 pathogen. So, it can be said that there remains risk of bacterial disease while handling them.

413 There were also some bacterial strains in the present study which were proved as pathogenic for 
414 shrimp from previous reports, especially $A$. venetianus. The antibiotic susceptibility test proved

415 that there were antibiotic resistant bacteria present in the study sites and most of the isolates

416 showed multidrug resistance. From this study, it may be concluded that shrimp PL nurseries in

417 southern part of Bangladesh are getting contaminated with the potentially pathogenic bacteria

418 either through sea water they are getting from the open sea for rearing the PL or from vertical

419 transmission of broodstock to PL, the feed they used for PL rearing and poor hygiene

420 maintenance. Therefore, it is very important to pay attention to good rearing practice, hygiene,

421 controlled use of antibiotic supplemented feed and overall bio-security measures in the shrimp

422 PL nurseries and rearing farms.

\section{Acknowledgements}

424 The study was supported by the research fund of the Ministry of Science and Technology,

425 Bangladesh for 2018-2019 fiscal year. The authors wish to express deep gratitude to the shrimp

426 PL nursery owners from where the samples were collected for the investigation. The authors are

427 grateful to the Invent Technologies Ltd., Bangladesh for their kind cooperation during the study.

\section{References}

429 Ali H, Rico A, Murshed-e-Jahan K, Belton B (2016) An assessment of chemical and biological

430 product use in aquaculture in Bangladesh. Aquaculture 454:199-209

431 APHA (1998) Standard methods for the examination of water and wastewater. 20th Edition.

432 American Public Health Association (APHA), Washington DC, p 1325

433 Austin B, Austin D, Sutherland R, Thompson F, Swings J (2005) Pathogenicity of vibrios to

434 rainbow trout (Oncorhynchus mykiss, Walbaum) and Artemia nauplii. Environ Microbiol

$435 \quad 7: 1488-1495$ 
436 Bachere E, Mialhe E, Noel D, Boul V, Morvan A, Rodrigues J (1995) Knowledge and research 437 prospects in marine mollusk and crustacean immunology. Aquaculture 132:17-32

Banerjee S, Khatoon H, Shariff M, Fatimah, Yusoff M (2010) Enhancement of Penaeus monodon shrimp postlarvae growth and survival without water exchange using marine Bacillus pumilus and periphytic microalgae. Fish Sci 76:481-487

Bauer AW, Kirby WMM, Sherris JC, Truck M (1966) Antibiotic susceptibility testing by a standardized single disk method. Am J Clin Pathol 45:493-496

Behera BK, Paria P, Das A, Bhowmick S, Sahoo AK, Das BK (2017) Molecular characterization and pathogenicity of a virulent Acinetobacter baumannii associated with mortality of farmed Indian Major Carp Labeo rohita (Hamilton 1822). Aquaculture 471:157-162

Cai J, Chen H, Thompson KD, Li C (2006) Isolation and identification of Shewanella alga and its pathogenic effects on post-larvae of abalone Haliotis diversicolor supertexta. J Fish Dis 29:505-508

Cao HP, Ye WD, He S, Li Y, Yang YB (2016) Acinetobacter lwoffii: an emerging pathogen of red-head disease in farmed channel catfish Ictalurus punctatus. Isr J Aquacult-Bamidgeh $68: 1325$

Cao HP, Yu LX, Ou RJ, Lu LQ, Yang, XL, Yang, YB (2017) Acinetobacter johnsonii: an emerging pathogen for cultured blunt snout bream Megalobrama amblycephala. Isr $\mathbf{J}$ Aquacult-Bamidgeh 69:1368

Chang C, Chaoqun H, Xiaoyan C, Luping Z (2003) Identification and characterization of Shewanella algae as a novel pathogen of ulcer disease of fish Scinenops ocellata. Oceanol Limnol Sin 34:1-8 
458 Chanratchakool P, Pearson M, Limsuwan C, Roberts RJ (1995) Oxytetracycline sensitivity of

$459 \quad$ Vibrio species isolated from diseased black tiger shrimp Penaeus monodon Fabricius. J Fish

$460 \quad$ Dis 18:79-82

461 Chi TTK, Clausen JH, Van PT, Tersbøl B, Dalsgaard A (2017) Use practices of antimicrobials

462 and other compounds by shrimp and fish farmers in Northern Vietnam. Aquacult Rep 7:40-

$463 \quad 47$

465

466

467

468

469

470

471

472

473

474

475

476

477

478

479
464 CLSI (2013) Performance standards for antimicrobial susceptibility testing; twenty-third informational supplement. CLSI document M100-S23. Clinical and Laboratory Standards Institute. Wayne, PA, USA.DoF (2020) National Fish Week 2020 Compendium (in Bangla). Department of Fisheries, Ministry of Fisheries and Livestock, Bangladesh, p 160

Dong X, Wang H, Xie G, Zou P, Guo C, Liang Y, et al. (2017) An isolate of Vibrio campbellii carrying the pirVP gene causes acute hepatopancreatic necrosis disease. Emerg Microbes Infect 6:131-132

Eshik MME, Punom NJ, Begum MK, Khan T, Saha ML, Rahman MS (2018) Molecular characterization of acute hepatopancreatic necrosis disease causing Vibrio parahaemolyticus strains in cultured shrimp Penaeus monodon in south-west farming region of Bangladesh. Dhaka Univ J Biol Sci 27:57-68

Eshik MME, Abedin MM, Punom NJ, Begum MK, Rahman MS (2017) Molecular identification of AHPND positive Vibrio Parahaemolyticus causing an outbreak in south-west shrimp farming regions of Bangladesh. J Bangladesh Acad Sci 41:127-135.

Failmezger J, Scholz S, Blombach B, Siemann-Herzberg M (2018) Cell-free protein synthesis from fast-growing Vibrio natriegens. Front Microbiol 9:1146

Peer) reviewing PDF | (2021:07:64200:2:0:NEW 11 Dec 2021) 
480 FAO (2006) The State of World Fisheries and Aquaculture. Food and Agricultural Organization 481 of the United Nations, Rome.

482 FAO (2013) Report of the FAO/MARD technical workshop on early mortality syndrome (EMS) 483 or acute hepatopancreatic necrosis syndrome (AHPNS) of cultured shrimp (under TCP/VIE/3304). Hanoi, Viet Nam, 25-27 June 2013. FAO Fisheries and Aquaculture Report No. 1053. p 54

486

487

488

489

490

491

492

493

494

495

496

497

498

499

500

501

Gomez-Gil B, Tron-Maye'n L, Roque A, Turnbull JF, Inglis V, Guerra-Flores AL (1998) Species of Vibrio isolated from hepatopancreas, haemolymph and digestive tract of a population of healthy juvenile Penaeus vannamei. Aquaculture 163:1-9

Hannan MA, Rahman MM, Mondal MN, Deb SC, Chowdhury G, Islam MT (2019) Molecular identification of Vibrio alginolyticus causing vibriosis in shrimp and its herbal remedy. Polish J Microbiol 68:429-438

Hinchliffe S (2019) Production without medicalization. Report from workshop on AMR, One Health and Aquaculture, Dhaka, Bangladesh. February 12-13th 2019.

Holmstrom K, Graslund S, Wahlstrom A, Poungshompoo S, Bengtsson BE, Kautsky N (2003) Antibiotic use in shrimp farming and implications for environmental impacts and human health. Int J Food Sci Tech 38:255-266

Holt H, Gahrn-Hansen B, Bruun B (2005) Shewanella algae and Shewanella putrefaciens: clinical and microbiological characteristics. Clin Microbiol Infect 11:347-352

Huang X, Gu Y, Zhou H, Xu L, Cao H, Gai C (2020) Acinetobacter venetianus, a potential pathogen of red leg disease in freshwater-cultured whiteleg shrimp Penaeus vannamei. Aquac Rep 18:100543 
502 Jannat M, Ahmed MK, Islam MM, Kundu GK, Kamruzzaman M (2017) Shrimp post-larvae

$503 \quad$ nursing in earthen ponds, Bangladesh. J Sci Res 9:97-107

504 Kang CH, Shin Y, Jang S, Jung Y, So JS (2016) Antimicrobial susceptibility of Vibrio

505 alginolyticus isolated from oyster in Korea. Environ Sci Pollut Res 23:21106-21112

506 Kannan S, Krishnamoorthy G, Kulanthaiyesu A, Marudhamuthu M (2019) Effect of

507 biosurfactant derived from Vibrio natriegens MK3 against Vibrio harveyi biofilm and

$508 \quad$ virulence. J Basic Microbiol 59:936-949

509 Karim R, Uddin N, Uddin A (2017) Microbiological and biochemical analysis of water and soil

510 sample exist in coastal shrimp aquaculture production system of Bangladesh. Saudi J Pathol

$511 \quad$ Microbiol 2:291-297

512 Karunasagar I, Otta SK, Karunasagar I (1997) Histopathological and bacteriological study of

$513 \quad$ white spot syndrome of Penaeus monodon along the west coast of India. Aquaculture 153:9-

$514 \quad 13$

515 Kennedy B, Venugopal MN, Karunasagar I, Karunasagar I (2006) Bacterial flora associated with

516 the giant freshwater prawn Macrobrachium rosenbergii in the hatchery system. Aquaculture

$517 \quad 261: 1156-1167$

518 Kittinger C, Lipp M, Baumert R, Folli B, Koraimann G, Toplitsch D, Liebmann A, Grisold AJ,

519 Farnleitner AH, Kirschner A, Zarfel G (2016) Antibiotic resistance patterns of Pseudomonas

520 spp. isolated from the river Danube. Front Microbiol 7:586

521 Kondo H, Phan TV, Dang LT, Hirono I (2015) Draft genome sequence of non- $V$.

522 parahaemolyticus acute hepatopancreatic necrosis disease strain $\mathrm{KC} 12.17 .5$, isolated from

523 diseased shrimp in Vietnam. Genome Announc 3: e00978-15. 
524 Kozinska A, Paździor E, Pękala A, Niemczuk W (2014). Acinetobacter johnsonii and

525 Acinetobacter lwoffii - the emerging fish pathogens. Bull Vet Inst Pulawy 58:193-199

526 Krumperman PH (1983) Multiple antibiotic resistance indexing of Escherichia coli to identify

527 high-risk sources of fecal contamination of foods. Appl Environ Microbiol 46:165-170

528 Kumar S, Stecher G, Li M, Knyaz C, Tamura K (2018) MEGA X: Molecular Evolutionary

529 Genetics Analysis across computing platforms. Mol Biol Evol 35:1547-1549

530 Lavilla-Pitogo CR, de la Pena LD (1998) Bacterial disease in shrimp (Penaeus monodon) culture

531 in the Philippines. Fish Pathol 33:405-411

532 Lavilla-Pitogo CR (1995) Bacterial diseases of penaeid shrimps an Asian view. In: Shariff M,

533 Arthur JR, Subasinghe RP (eds) Diseases in Asian Aquaculture II, Fish health section. Asian

$534 \quad$ Fisheries Society, Manila, Philippines, p 107-121

535 Lightner DV (2003) Exclusion of specific pathogens for disease control in a penaeid shrimp

536 biosecurity program. In: Lee CS, O’Bryen PJ (eds) Biosecurity in aquaculture production

537 systems: Exclusion of pathogens and other undesirables. World Aquaculture Society, Baton

$538 \quad$ Rouge, Louisiana, USA, p 81-116

539 Li G, Xie G, Wang H, Wan X, Li X, Shi C, Wang Z, Gong M, Li T, Wang P, Zhang Q, Huang

540 J (2021) Characterization of a novel shrimp pathogen, Vibrio brasiliensis, isolated from

$541 \quad$ Pacific white shrimp, Penaeus vannamei. J Fish Dis 44:1543- 1552.

542 Lin YT, Shieh WY (2006) Zobellella denitrificans gen. nov., sp. nov. and Zobellella taiwanensis

543 sp. nov., denitrifying bacteria capable of fermentative metabolism. Int J Syst Evol Micr

$544 \quad 56: 1209-1215$ 
545 Liu C, Cheng W, Hsu J, Chen J (2004) Vibrio alginolyticus infection in the white shrimp

546 Litopenaeus vannamei confirmed by polymerase chain reaction and 16S rDNA sequencing.

547 Dis Aquat Organ 61:169-174

548 Liu L, Xiao J, Zhang M, Zhu W, Xia X, Dai X, Pan Y, Yan S, Wang Y (2018) A Vibrio

549 owensii strain as the causative agent of AHPND in cultured shrimp, Litopenaeus vannamei. J

$550 \quad$ Invertebr Pathol 153: 156-164.

551 Longyant S, Rukpratanporn S, Chaivisuthangkura P, Suksawad P, Srisuk C, Sithigorngul W,

552 Piyatiratitivorakul S, Sithigorngul P (2008) Identification of Vibrio spp. in vibriosis Penaeus

553 vannamei using developed monoclonal antibodies. J Invertebr Pathol 98:63-68

554 Malick RC, Bera AK, Chowdhury H, Bhattacharya M, Abdulla T, Swain HS, Baitha R, Kumar

555 V, Das BK (2020) Identification and pathogenicity study of emerging fish pathogens

556 Acinetobacter junii and Acinetobacter pittii recovered from a disease outbreak in Labeo catla

557 (Hamilton, 1822) and Hypophthalmichthys molitrix (Valenciennes, 1844) of freshwater

558 wetland in West Bengal, India. Aquac Res 51:2410-2420

559 Matin MA, Chakraborty S, Al Amin M, Ghosh A (2016) An assessment of shrimp aquaculture in

560 selected coastal areas of Bangladesh. J NOAMI 33:103-116

561 Murray AK (2020) The novel coronavirus COVID-19 outbreak: global implications for

$562 \quad$ antimicrobial resistance. Front Microbiol 11:1020

563 Muthukrishnan S, Defoirdt T, Ina-Salwany MY, Yusoff FM, Shariff M, Ismail SI, Natrah I

564 (2019) Vibrio parahaemolyticus and Vibrio harveyi causing Acute Hepatopancreatic

565 Necrosis Disease (AHPND) in Penaeus vannamei (Boone, 1931) isolated from Malaysian

$566 \quad$ shrimp ponds. Aquaculture 511:734227 
567 Nash G, Charetana N, Cholada T, Anutra A, Phusit P, Pongcham R (1992) Vibriosis and its

568 control in pond-reared Penaeus monodon in Thailand. In: Shariff M, Subasinghe RP, Arthur

569 JR (eds) Diseases in Asian Aquaculture I. Asian Fisheries Society, Philippines, p 143-155

570 Nayak SK (2021) Multifaceted applications of probiotic Bacillus species in aquaculture with $571 \quad$ special reference to Bacillus subtilis. Rev Aquacult 13: 862-906.

572 Noorlis A, Ghazali FM, Cheah YK, Zainazor TCT, Wong WC, Tunung R, Pui CF, Nishibuchi 573 M, Nakaguchi Y, Son R (2011) Antibiotic resistance and biosafety of Vibrio cholerae and $574 \quad$ Vibrio parahaemolyticus from freshwater fish at retail level. Int Food Res J 18:1523-1530

575 Nurhafizah WWI, Lee KL, Laith A AR, Nadirah M, Danish-Daniel M, Zainathan SC, Najiah M

576 (2021) Virulence properties and pathogenicity of multidrug-resistant Vibrio harveyi

577 associated with luminescent vibriosis in pacific white shrimp, Penaeus vannamei. J Invertebr $578 \quad$ Pathol 186:107594

579 Nuruzzaman M (2006) Dynamics and diversity of shrimp farming in Bangladesh: technical 580 aspects. In: Rahman AA, Quddus AHG, Pokrant B, Ali ML (eds) Shrimp farming and 581 industry: sustainability, trade and livelihoods, BCAS/UPL, Dhaka, Bangladesh. p 431-460

582 Ping L, Zhang C, Cui H, Yuan X, Cui J, Shan S (2017) Characterization and application of a 583 newly isolated pyrene-degrading bacterium, Pseudomonas monteilii. 3 Biotech 7:309

584 Prayitno SB, Latchford JW (1995) Experimental infections of crustaceans with luminous bacteria 585 related to Photobacterium and Vibrio spp. effect of salinity and $\mathrm{pH}$ on infectiosity. 586 Aquaculture 132:105-112

587 Punom NJ, Hasan AKMM, Haque W, Begum MK, Rahman MS (2016) 16S rRNA sequence 588 based identification of pathogenic gut microbiota of Rohu Labeo rohita (Hamilton-Buchanan 
Sci $25: 169-184$

591

592

593

594

595

596

597

598

599

600

601

602

603

604

605

606

607

608

609

610

Qi X, Xue M, Cui H, Yang K, Song K, Zha J, Wang G, Ling F (2020) Antimicrobial activity of Pseudomonas monteilii JK-1 isolated from fish gut and its major metabolite, 1hydroxyphenazine, against Aeromonas hydrophila. Aquaculture 526:735366

Rahman MS, Martino ME, Cardazzo B, Facco P, Bordin P, Mioni R, Novelli E, Fasolato L (2014) Vibrio trends in the ecology of the Venice Lagoon. Appl Environ Microbiol 80: 23722380

Rahman MS, Eshik MME, Punom NJ, Abedin MM, Begum MK (2020) Diversity of Vibrio species' and their antibiotic resistance patterns in black tiger shrimp Penaeus monodon Fabricius, 1798 cultured in south-west region of Bangladesh. Asian Fish Sci 33:330-340

Reboucas RH, de Sousa OV, Lima AS, Vasconcelos FR, de Carvalho PB, Vieira RH (2011) Antimicrobial resistance profile of Vibrio species isolated from marine shrimp farming environments (Litopenaeus vannamei) at Ceará, Brazil. Environ Res 111:21-24

Restrepo L, Bayot B, Arciniegas S, Bajana L, Betancourt I, Panchana F, et al. (2018) PirVP genes causing AHPND identified in a new Vibrio species (Vibrio punensis) within the commensal Orientalis clade. Sci Rep 8:13080.

Rey MW, Ramaiya, Nelson BA, Brody-Karpin SD, Zaretsky EJ, Tang M, Lopez de Leon A, Xiang H, Gusti V, Clausen IG, Olsen PB, Rasmussen MD, Andersen JT, Jørgensen PL, Larsen TS, Sorokin A, Bolotin A, Lapidus A, Galleron N, Ehrlich SD, Berka RM (2004) Complete genome sequence of the industrial bacterium Bacillus licheniformis and comparisons with closely related Bacillus species. Genome Biol 5:R77 
611 Satomi M (2014) The family shewanellaceae. In: DeLong EF, Lory S, Stackebrandt E,

612 Thompson F (eds) The Prokaryotes. Springer Berlin Heidelberg, p 597-625

613 Schwarz S, Silley P, Simjee S, Woodford N, van Duijkeren E, Johnson AP, Gaastra W (2010)

614 Editorial: assessing the antimicrobial susceptibility of bacteria obtained from animals. J

615 Antimicrob Chemother 65:601-604

616 Selvin J, Lipton AP (2003) Vibrio alginolyticus associated with white spot disease of Penaeus 617 monodon. Dis Aquat Organ 57:147-150

618 Shakir Z, Khan S, Sung K, Khare S, Khan A, Steele R, Nawaz M (2012) Molecular

619 characterization of fluoroquinolone-resistant Aeromonas spp. isolated from imported shrimp.

$620 \quad$ Appl Environ Microbiol 8:8137-8141

621 Shamsuzzaman MM, Biswas TK (2012) Aqua chemicals in shrimp farm: a study from south622 west coast of Bangladesh. Egypt J Aquat Res 38: 275-285

623 Sotomayor MA, Reyes JK, Restrepo L, Domı'nguez-Borbor C, Maldonado M, Bayot B (2019)

624 Efficacy assessment of commercially available natural products and antibiotics, commonly 625 used for mitigation of pathogenic Vibrio outbreaks in Ecuadorian Penaeus (Litopenaeus)

626 vannamei hatcheries. PLoS One 14: e0210478

627 Thompson FL, Li Y, Gomez-Gil B, Thompson CC, Hoste B, Vandemeulebroecke K, Rupp GS, 628 Pereira A, De Bem MM, Sorgeloos P, Swings J (2003) Vibrio neptunius sp. nov., Vibrio 629 brasiliensis sp. nov. and Vibrio xuii sp. nov., isolated from the marine aquaculture 630 environment (bivalves, fish, rotifers and shrimps). Int J Syst Evol Micr 53:245-252

631 Thuy HTT, Nga LP, Loan TTC (2011) Antibiotic contaminants in coastal wetlands from 632 Vietnamese shrimp farming. Environ Sci Pollut Res 18: 835-841 
633 Torres JL (2007) Bacterial loads in hatcheries and virulence of Vibrio spp. to larvae of the tiger

634 shrimp Penaeus monodon. In: Bagarinao TU (eds) Research output of the Fisheries sector

635 program. Bureau of Agricultural Research, Department of Agriculture, Philippines.

636 Uddin SA, Kader MA (2006) The use of antibiotics in shrimp hatcheries in Bangladesh. J Fish

637 Aquat Sci 1: 64-67

638 Vaneechoutte M, Nemec A, Musílek M, van der Reijden TJK, van den Barselaar M, Tjernberg I,

639 Calme W, Fani R, Baere TD, Dijkshoorn L (2009) Description of Acinetobacter venetianus

640 ex Di Cello et al. 1997 sp. nov. Int J Syst Evol Micr 59:1376-1381

641 Vaseeharan B, Ramasamy P (2003) Abundance of potentially pathogenic micro-organisms in

642 Penaeus monodon larvae rearing systems in India. Microbiol Res 158:299-308

643 Veith B, Herzberg C, Steckel S, Feesche J, Maurer KH, Ehrenreich P, Bäumer S, Henne A,

644 Liesegang H, Merkl R, Ehrenreich A, Gottschalk G (2004) The complete genome sequence

645 of Bacillus licheniformis DSM13, an organism with great industrial potential. J Mol

$646 \quad$ Microbiol Biotechnol 7:204-211

647 Vignier N, Théodose R, Barreau M, Baubion E, Olive C, Cabié A, Hochedez P (2013) Human

648 infection with Shewanella putrefaciens and S. algae: Report of 16 cases in martinique and

649 review of the literature. Am J Trop Med Hyg 89:151-156

650 Weisburg WG, Barns SM, Pelletier DA, Lane DJ (1991) 16S ribosomal DNA amplification for

651 phylogenetic study. J Bacteriol 173:697-703

652 WHO 2015. Global action plan on antimicrobial resistance. World Health Organization, Geneva, 653 Switzerland.

654 Wu YW, Yang SH, Hwangbo M, Chu KH (2019) Analysis of Zobellella denitrificans ZD1 draft 655 genome: Genes and gene clusters responsible for high polyhydroxybutyrate (PHB) 
656 production from glycerol under saline conditions and its CRISPR-Cas system. PLoS One 657 14(9):e0222143

658 Yano Y, Hamano K, Tsutsui I, Aue-umneoy D, Ban M, Satomi M (2015) Occurrence, molecular 659 characterization, and antimicrobial susceptibility of Aeromonas spp. in marine species of 660 shrimps cultured at inland low salinity ponds. Food Microbiol 47:21-27

661 Yousfi K, Bekal S, Usongo V, Touati A (2017) Current trends of human infections and antibiotic 662 resistance of the genus Shewanella. Eur J Clin Microbiol Infect Dis 36: 1353-1362 


\section{Table $\mathbf{1}$ (on next page)}

Colony morphology of bacterial isolates

Colony morphology of representative thirty bacterial isolates from eight different shrimp PL nurseries of Khulna and Satkhira 
Table 1 Colony morphology of representative thirty bacterial isolates from eight different shrimp PL nurseries of Khulna and Satkhira

\begin{tabular}{|c|c|c|c|c|c|c|c|}
\hline Isolate No. & Sample code & $\begin{array}{l}\text { Sampling } \\
\text { location }\end{array}$ & Sample source & $\begin{array}{l}\text { Culture } \\
\text { media }\end{array}$ & $\begin{array}{l}\text { Culture } \\
\text { condition }\end{array}$ & Colony color & Size \\
\hline YPL1-2 & YPL1/MSA/1 & Khulna & PL & MSA & Direct plating & Pinkish & Small \\
\hline YPL1-4 & YPL1/TCBS/1 & Khulna & PL & TCBS & Direct plating & Greenish & Small \\
\hline YWO1-12 & YWO1/MSA/1 & Khulna & Outlet water & MSA & Direct plating & Whitish & Small \\
\hline YWO1-14 & YWO1/TCBS/6h/1 & Khulna & Outlet water & TCBS & APW enrichment & Greenish & Small \\
\hline YPL2-16 & YPL2/MSA/1 & Khulna & PL & MSA & Direct plating & Whitish red & Small \\
\hline YPL2-18 & YPL2/TCBS/6h/1 & Khulna & PL & TCBS & APW enrichment & Yellowish & Small \\
\hline YPL2-19 & YPL2/ TCBS/6h/2 & Khulna & PL & TCBS & APW enrichment & Greenish & Small \\
\hline YPL2-20 & YPL2/TCBS/Raw & Khulna & PL & TCBS & Direct plating & Greenish yellow & Small \\
\hline YWR2-22 & YWR2/TCBS/Raw/1 & Khulna & Raw sea water & TCBS & Direct plating & Greenish & Large \\
\hline YWR2-23 & YWR2/MSA/1 & Khulna & Raw sea water & MSA & Direct plating & Whitish & Small \\
\hline YWO3-27 & YWO3/SS/1 & Khulna & Outlet water & $\mathrm{SS}$ & Direct plating & Pinkish & Large \\
\hline YWO3-29 & YWO3/TCBS/1 & Khulna & Outlet water & TCBS & Direct plating & Yellowish & Large \\
\hline YPL3-35 & YPL3/EMB/1 & Khulna & PL & EMB & Direct plating & Pinkish & Small \\
\hline YWT4-39 & YWT4/EMB/1 & Khulna & Treated water & EMB & Direct plating & Pinkish & Small \\
\hline YPL4-52 & YPL4/TCBS/6h/3 & Khulna & PL & TCBS & APW enrichment & Yellowish & Medium \\
\hline YWT5-55 & YWT5/MSA/2 & Khulna & Treated water & MSA & Direct plating & Yellowish & Large \\
\hline YWO5-61 & YWO5/ SS/1 & Khulna & Outlet water & SS & Direct plating & Colorless & Medium \\
\hline YPL5-62 & YPL5/EMB/1 & Khulna & PL & EMB & Direct plating & Pinkish & Medium \\
\hline
\end{tabular}




\begin{tabular}{llllllll}
\hline YPL5-64 & YPL5/SS/1 & Khulna & PL & SS & Direct plating & Colorless & Medium \\
YWT6-68 & YWT6/MSA/1 & Satkhira & Treated water & MSA & Direct plating & Cream & Small \\
YW06-72 & YWO6/MSA/1 & Satkhira & Outlet water & MSA & Direct plating & Cream & Large \\
YPL6-75 & YPL6/SS/1 & Satkhira & PL & SS & Direct plating & Cream & Small \\
YWR7-79 & YWR7/EMB/1 & Satkhira & Raw sea water & EMB & Direct plating & Pinkish & Small \\
YWT7-80 & YWT7/TCBS/6h/1 & Satkhira & Treated water & TCBS & APW enrichment & Yellow & Large \\
YWO7-86 & YWO7/EMB/1 & Satkhira & Outlet water & EMB & Direct plating & Pinkish & Small \\
YPL7-89 & YPL7/SS/1 & Satkhira & PL & SS & Direct plating & Pinkish & Small \\
YWR8-91 & YWR8/EMB/1 & Satkhira & Raw sea water & EMB & Direct plating & Pinkish & Small \\
YWT8-94 & YWT8/SS/1 & Satkhira & Treated water & SS & Direct plating & Pink & Small \\
YWO8-97 & YWO8/EMB/1 & Satkhira & Outlet water & EMB & Direct plating & Purple & Small \\
YPL8-98 & YPL8/EMB/2 & Satkhira & PL & EMB & Direct plating & Pinkish & Small \\
\hline
\end{tabular}

$2 *$ Small when diameter is $\leq 1 \mathrm{~mm}$, Medium when diameter is $1.1-\leq 2 \mathrm{~mm}$, Large when diameter is $>2 \mathrm{~mm}$. 


\section{Table 2 (on next page)}

Identification of bacterial isolates

Identification of thirty representative bacterial isolates by nucleotide BLAST search of NCBI database using 16S rRNA gene sequences. 
2 sequences.

\begin{tabular}{|c|c|c|c|c|c|c|c|c|c|c|}
\hline $\begin{array}{l}\text { Serial } \\
\text { no. }\end{array}$ & $\begin{array}{l}\text { Isolate no. } \\
\text { (Strain } \\
\text { designation) }\end{array}$ & Identified species & $\begin{array}{l}\text { Most } \\
\text { relevant } \\
\text { strain name }\end{array}$ & $\begin{array}{l}\text { Length of } \\
\text { sequences } \\
\text { (bp) }\end{array}$ & $\begin{array}{l}\text { Max } \\
\text { Score }\end{array}$ & $\begin{array}{l}\text { Query } \\
\text { cover }\end{array}$ & $\begin{array}{l}\text { E } \\
\text { Value }\end{array}$ & $\begin{array}{l}\text { Identity } \\
\text { Match }\end{array}$ & $\begin{array}{l}\text { GenBank } \\
\text { accession no. } \\
\text { of } \\
\text { corresponding } \\
\text { sequence }\end{array}$ & $\begin{array}{l}\text { GenBank } \\
\text { accession } \\
\text { no. of } \\
\text { studied } \\
\text { strains }\end{array}$ \\
\hline 1 & YPL1-2 & Vibrio xuii & DSM17185 & 1137 & 2100 & $100 \%$ & 0.0 & $100 \%$ & MH315813.1 & MT368010 \\
\hline 2 & YPL1-4 & V. shilonii & VSS-012 & 1426 & 2634 & $100 \%$ & 0.0 & $100 \%$ & FJ485944.1 & MT368011 \\
\hline 3 & YWO1-12 & Bacillus licheniformis & R-QL-77-10 & 1427 & 2636 & $100 \%$ & 0.0 & $100 \%$ & MT078630.1 & MT368012 \\
\hline 4 & YWO1-14 & V. shilonii & VSS-012 & 1422 & 2627 & $100 \%$ & 0.0 & $100 \%$ & FJ485944.1 & MT368013 \\
\hline 5 & YPL2-16 & V. natriegens & P14-2 & 1422 & 2627 & $100 \%$ & 0.0 & $100 \%$ & KC261284.1 & MT368014 \\
\hline 6 & YPL2-18 & V. parahaemolyticus & 19-021-D1 & 1423 & 2628 & $100 \%$ & 0.0 & $100 \%$ & СР046411.1 & MT368015 \\
\hline 7 & YPL2-19 & V. shilonii & VSS-012 & 1425 & 2632 & $100 \%$ & 0.0 & $100 \%$ & FJ485944.1 & MT368016 \\
\hline 8 & YPL2-20 & V. alginolyticus & $5-19$ & 1424 & 2630 & $100 \%$ & 0.0 & $100 \%$ & MN945282.1 & MT368017 \\
\hline 9 & YWR2-22 & V. brasiliensis & $\mathrm{XSH}$ & 1426 & 2571 & $100 \%$ & 0.0 & $99.23 \%$ & MT071607.1 & MT368018 \\
\hline 10 & YWR2-23 & Bacillus pumilus & 10B2-13 & 1420 & 2623 & $100 \%$ & 0.0 & $100 \%$ & MK603127.1 & МТ368019 \\
\hline 11 & YWO3-27 & V. alginolyticus & $5-19$ & 1423 & 2628 & $100 \%$ & 0.0 & $100 \%$ & MN945282.1 & MT368020 \\
\hline 12 & YWO3-29 & V. alginolyticus & $5-19$ & 1426 & 2634 & $100 \%$ & 0.0 & $100 \%$ & MN945282.1 & MT368021 \\
\hline 13 & YPL3-35 & $\begin{array}{l}\text { Acinetobacter } \\
\text { venetianus }\end{array}$ & PFBCI & 1409 & 2603 & $100 \%$ & 0.0 & $100 \%$ & LN875372.1 & MT368022 \\
\hline
\end{tabular}




\begin{tabular}{|c|c|c|c|c|c|c|c|c|c|c|}
\hline 14 & YWT4-39 & A. venetianus & ICP1 & 1417 & 2617 & $100 \%$ & 0.0 & $100 \%$ & MN542884.1 & MT368023 \\
\hline 15 & YPL4-52 & V. shilonii & VSS-012 & 1423 & 2628 & $100 \%$ & 0.0 & $100 \%$ & FJ485944.1 & MT368024 \\
\hline 16 & YWT5-55 & V. brasiliensis & IS014 & 1425 & 2569 & $100 \%$ & 0.0 & $99.23 \%$ & KR186076.1 & MT368025 \\
\hline 17 & YWO5-61 & Zobellella denitrificans & F13 & 1417 & 2612 & $100 \%$ & 0.0 & $99.93 \%$ & СР012621.1 & MT368026 \\
\hline 18 & YPL5-62 & Aeromonas caviae & BTNGPSA3 & 1417 & 2617 & $100 \%$ & 0.0 & $100 \%$ & MK958566.1 & MT368027 \\
\hline 19 & YPL5-64 & Shewanella algae & SFH3 & 1422 & 2627 & $100 \%$ & 0.0 & $100 \%$ & MG738264.1 & MT368028 \\
\hline 20 & YWT6-68 & $V$. alginolyticus & FA2 & 1432 & 2645 & $100 \%$ & 0.0 & $100 \%$ & СР042449.1 & MT368029 \\
\hline 21 & YWO6-72 & $V$. alginolyticus & $5-19$ & 1430 & 2641 & $100 \%$ & 0.0 & $100 \%$ & MN945282.1 & MT368030 \\
\hline 22 & YPL6-75 & A. venetianus & PFBCI & 1375 & 2540 & $100 \%$ & 0.0 & $100 \%$ & LN875372.1 & MT368031 \\
\hline 23 & YWR7-79 & A. venetianus & PFBCI & 1373 & 2536 & $100 \%$ & 0.0 & $100 \%$ & LN875372.1 & МT368032 \\
\hline 24 & YWT7-80 & $V$. alginolyticus & $5-19$ & 1414 & 2612 & $100 \%$ & 0.0 & $100 \%$ & MN945282.1 & MT368033 \\
\hline 25 & YWO7-86 & A. venetianus & PFBCI & 1412 & 2608 & $100 \%$ & 0.0 & $100 \%$ & LN875372.1 & МТ368034 \\
\hline 26 & YPL7-89 & S. algae & SFH3 & 1423 & 2628 & $100 \%$ & 0.0 & $100 \%$ & MG738264.1 & MT368035 \\
\hline 27 & YWR8-91 & A. venetianus & $\mathrm{ICP} 1$ & 1375 & 2540 & $100 \%$ & 0.0 & $100 \%$ & MN542884.1 & MT368036 \\
\hline 28 & YWT8-94 & S. algae & SFH3 & 1416 & 2615 & $100 \%$ & 0.0 & $100 \%$ & MG738264.1 & МT368037 \\
\hline 29 & YWO8-97 & Pseudomonas monteilii & ER30 & 1412 & 2608 & $100 \%$ & 0.0 & $100 \%$ & MT124555.1 & МТ368038 \\
\hline 30 & YPL8-98 & $\begin{array}{l}\text { Pseudomonas sp. } \\
\text { (not in full length) }\end{array}$ & YX6 & 630 & 1157 & $99 \%$ & 0.0 & $99.84 \%$ & KP789459.1 & $\begin{array}{l}\text { Not } \\
\text { submitted }\end{array}$ \\
\hline
\end{tabular}




\section{Table 3 (on next page)}

Identified bacterial isolates

Identified bacterial isolates in four different types of samples collected from eight different shrimp PL nurseries. 
1 Table 3 Identified bacterial isolates in four different types of samples collected from eight

2 different shrimp PL nurseries.

\begin{tabular}{|c|c|}
\hline $\begin{array}{l}\text { Types of } \\
\text { sample }\end{array}$ & Isolate No. (Identified species) \\
\hline $\begin{array}{l}\text { Raw } \\
\text { seawater }\end{array}$ & $\begin{array}{l}\text { YWR2-22 ( } \text {. brasiliensis), YWR2-23 (B. pumillus), YWR7-79 (A. venetianus), } \\
\text { YWR8-91 (A. venetianus), }\end{array}$ \\
\hline $\begin{array}{l}\text { Treated } \\
\text { water }\end{array}$ & $\begin{array}{l}\text { YWT4-39 (A. venetianus), YWT5-55 ( } \text {. brasiliensis), YWT6-68 (V. } \\
\text { alginolyticus), YWT7-80 (V. alginolyticus), YWT8-94 (S. algae) }\end{array}$ \\
\hline $\begin{array}{l}\text { Outlet } \\
\text { water }\end{array}$ & $\begin{array}{l}\text { YWO1-12 (B. licheniformis), YWO1-14 (V. shilonii), YWO3-27 ( } V . \\
\text { alginolyticus), YWO3-29 (V. alginolyticus), YWO5-61 (Z. denitrificans), YWO6- } \\
72 \text { (V. alginolyticus), YWO7-86 (A. venetianus), YWO8-97 (P. monteilii) }\end{array}$ \\
\hline $\begin{array}{l}\text { Shrimp } \\
\text { PL }\end{array}$ & $\begin{array}{l}\text { YPL1-2 ( } . \text { xuii), YPL1-4 ( } \text {. shilonii), YPL2-16 ( } \text {. natriegens), YPL2-18 ( } . \\
\text { parahaemolyticus), YPL2-19 ( } V . \text { shilonii), YPL2-20 ( } V . \text { alginolyticus }), \text { YPL3-35 } \\
\text { (A. venetianus), YPL4-52 ( } \text {. shilonii), YPL5-62 (A. caviae), YPL5-64 (S. algae), } \\
\text { YPL6-75 (A. venetianus), YPL7-89 (S. algae), YPL8-98 (Pseudomonas spp.) }\end{array}$ \\
\hline
\end{tabular}

3 


\section{Table 4 (on next page)}

Antibiotic susceptibility patterns of bacterial isolates

Antibiotic susceptibility patterns of thirty representative bacterial isolates from raw sea water, treated water, outlet water and PL samples collected from eight different shrimp PL nurseries against 12 antibiotics. 
2 PL samples collected from eight different shrimp PL nurseries against 12 antibiotics.

\begin{tabular}{|c|c|c|c|c|}
\hline \multirow{2}{*}{$\begin{array}{l}\text { Isolate } \\
\text { No. }\end{array}$} & \multirow[t]{2}{*}{ Identified species } & \multicolumn{3}{|l|}{ Antibiotic susceptibility } \\
\hline & & Sensitive & Intermediate & Resistant \\
\hline YPL1-2 & V. xuii & AMP, AZM, C, CIP, CRO, CN, TE, CAZ & - & E, SXT, W, P \\
\hline YPL1-4 & V. shilonii & AMP, AZM, C, CIP, CRO, CN, P, CAZ & $\mathrm{E}, \mathrm{TE}$ & SXT, W \\
\hline YWO1-12 & B. licheniformis & AMP, CIP, CRO, CN, SXT, W, P & AZM, C & E, TE, CAZ \\
\hline YWO1-14 & V. shilonii & AMP, AZM,C, CIP, CN, P, CAZ & TE & CRO,E, SXT,W, \\
\hline YPL2-16 & $V$. natriegens & AMP, AZM, C, CIP, CRO, E, SXT, P, CAZ & - & $\mathrm{CN}, \mathrm{W}, \mathrm{TE}$ \\
\hline YPL2-18 & V. parahaemolyticus & AMP, AZM, C, CIP, CRO, E, SXT, W, S & - & $\mathrm{CN}, \mathrm{P}, \mathrm{TE}$ \\
\hline YPL2-19 & V. shilonii & AMP, AZM, C, CRO, P, CAZ & CIP, TE & $\mathrm{E}, \mathrm{CN}, \mathrm{SXT}, \mathrm{W}$ \\
\hline YPL2-20 & $V$. alginolyticus & AMP, C, CRO, CN, SXT, W, CAZ & AZM, & CIP, E, P, TE \\
\hline YWR2-22 & V. brasiliensis & $\begin{array}{l}\text { AMP, AZM, C, CIP, CRO, E, SXT, W, P, } \\
\text { CAZ }\end{array}$ & $\mathrm{TE}$ & $\mathrm{CN}$ \\
\hline YWR2-23 & B. pumilus & AMP, AZM, C, CIP, E, CN, SXT, W, P & CRO, TE & CAZ \\
\hline YWO3-27 & V. alginolyticus & $\mathrm{C}, \mathrm{CRO}, \mathrm{CAZ}$ & $\mathrm{W}$ & AMP, AZM, CIP, E, CN, SXT, P, TE \\
\hline YWO3-29 & V. alginolyticus & AZM, C, CRO, SXT, W, CAZ & CIP, E, TE & $\mathrm{AMP}, \mathrm{CN}, \mathrm{P}$ \\
\hline YPL3-35 & A. venetianus & $\mathrm{AMP}, \mathrm{CN}, \mathrm{SXT}, \mathrm{CAZ}$ & $\mathrm{C}, \mathrm{CRO}$ & AZM, CIP, E, W, P, TE \\
\hline YWT4-39 & A. venetianus & AMP, AZM, C,CIP, CN, SXT, CAZ & $\mathrm{CRO}, \mathrm{E}$ & $\mathrm{W}, \mathrm{P}, \mathrm{TE}$ \\
\hline YPL4-52 & V. shilonii & $\mathrm{AMP}, \mathrm{C}, \mathrm{CN}, \mathrm{P}, \mathrm{CAZ}$ & AZM, CIP & $\mathrm{SXT}, \mathrm{W}, \mathrm{TE}$ \\
\hline YWT5-55 & V. brasiliensis & AMP, AZM, CIP, CRO, E, CN, CAZ & $\mathrm{TE}$ & $\mathrm{C}, \mathrm{SXT}, \mathrm{W}, \mathrm{P}$ \\
\hline
\end{tabular}




\begin{tabular}{|c|c|c|c|c|}
\hline YWO5-61 & Z. denitrificans & $\begin{array}{l}\text { AMP, AZM, C, CIP, CRO, SXT, W, P, } \\
\text { CAZ }\end{array}$ & $\mathrm{E}, \mathrm{TE}$ & $\mathrm{CN}$ \\
\hline YPL5-62 & A. caviae & AZM, C, CRO, SXT, W, CAZ & CIP,E & $\mathrm{AMP}, \mathrm{CN}, \mathrm{P}, \mathrm{TE}$ \\
\hline YPL5-64 & S. algae & $\mathrm{AZM}, \mathrm{CRO}, \mathrm{CN}, \mathrm{CAZ}$ & C, CIP & AMP, E, SXT, W, P, TE \\
\hline YWT6-68 & $V$. alginolyticus & AZM, C, CRO, SXT, W, CAZ & TE & AMP, CIP, E, CN, P \\
\hline YWO6-72 & V. alginolyticus & AZM, C, CRO, E, SXT, W, CAZ & CIP, TE & $\mathrm{AMP}, \mathrm{CN}, \mathrm{P}$ \\
\hline YWR7-79 & A. venetianus & CN, SXT, CAZ & $\mathrm{CRO}$ & AMP, AZM, C, CIP, E, W, P, TE \\
\hline YWT7-80 & $V$. alginolyticus & $\mathrm{C}, \mathrm{CRO}, \mathrm{SXT}, \mathrm{W}, \mathrm{CAZ}$ & $\mathrm{AZM}, \mathrm{TE}$ & AMP, CIP, E, CN, P \\
\hline YWO7-86 & A. venetianus & $\mathrm{C}, \mathrm{CN}$ & $\mathrm{CRO}, \mathrm{CAZ}$ & AMP, AZM, CIP, E, SXT, W, P, TE \\
\hline YWT8-94 & S. algae & AMP, AZM, CRO, P, CAZ & - & C, CIP, E, CN, SXT, W, TE \\
\hline YWO8-97 & P. monteilii & - & - & $\begin{array}{l}\text { AMP, AZM, C, CIP, CRO, E,CN, } \\
\text { AXT, W, P, TE, CAZ }\end{array}$ \\
\hline YPL8-98 & Pseudomonas sp. & $\mathrm{AZM}, \mathrm{CN}, \mathrm{CAZ}$ & $\mathrm{CRO}$ & AMP, C, CIP, E, SXT, W, P, TE \\
\hline
\end{tabular}




\title{
Figure 1
}

\author{
Locations map
}

Map showing the locations of studied shrimp PL nurseries in Khulna and Satkhira districts of Bangladesh created by ArcGIS version 10.8.

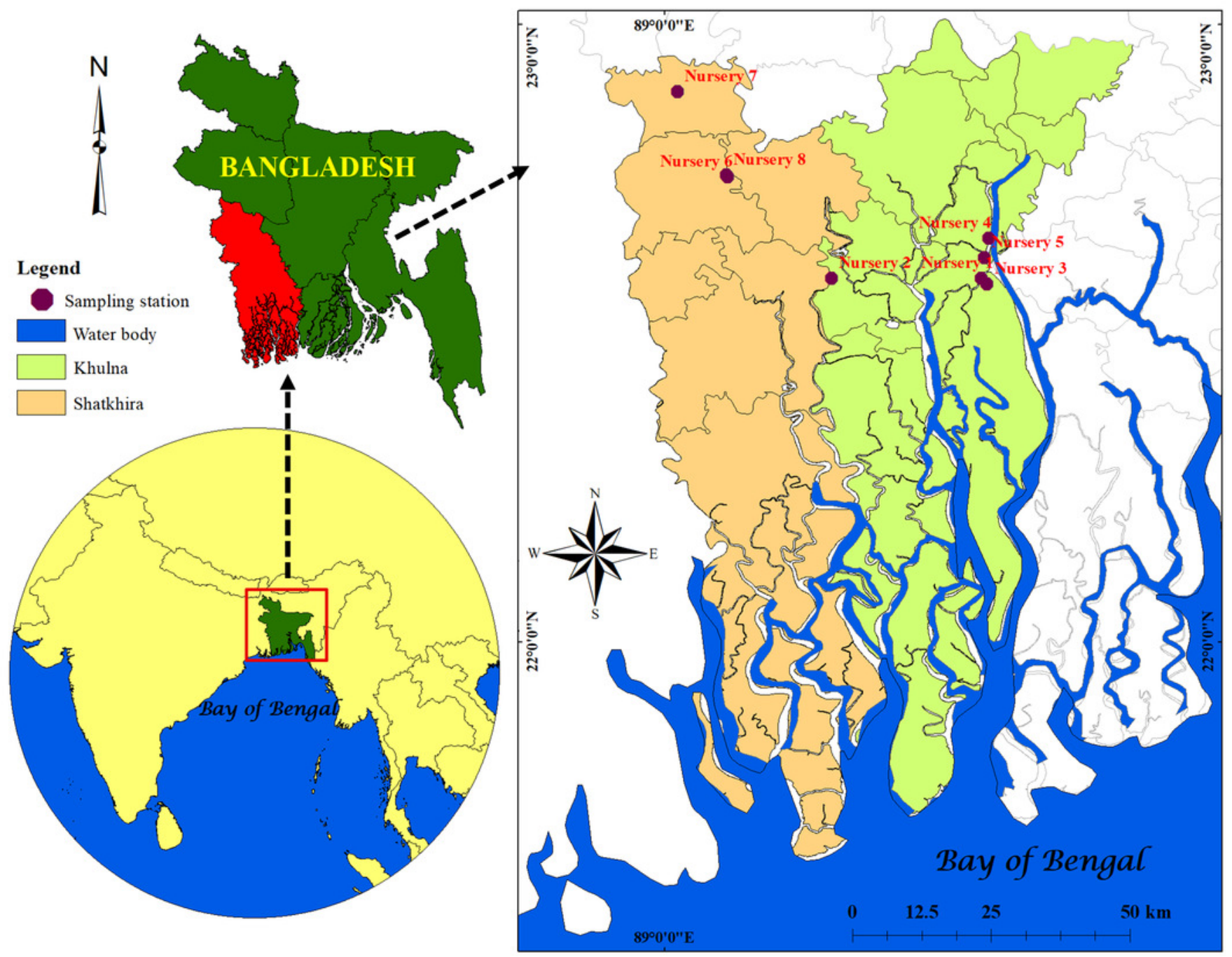




\section{Figure 2}

Gel photographs

Amplification of 16S rRNA gene of 30 representative bacterial isolates (A-C); L-denotes molecular marker and numbers denotes the representative bacterial isolates.

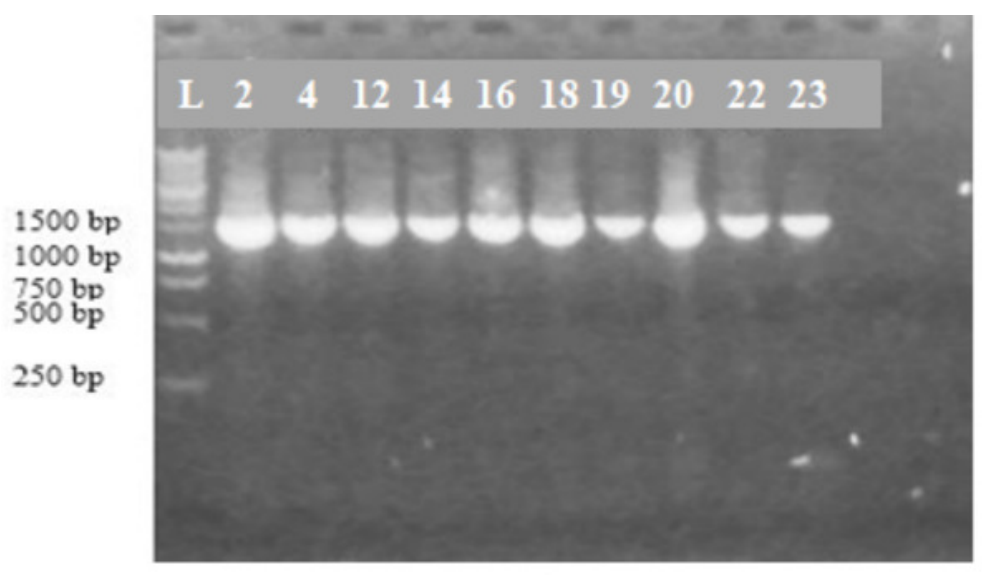

A.

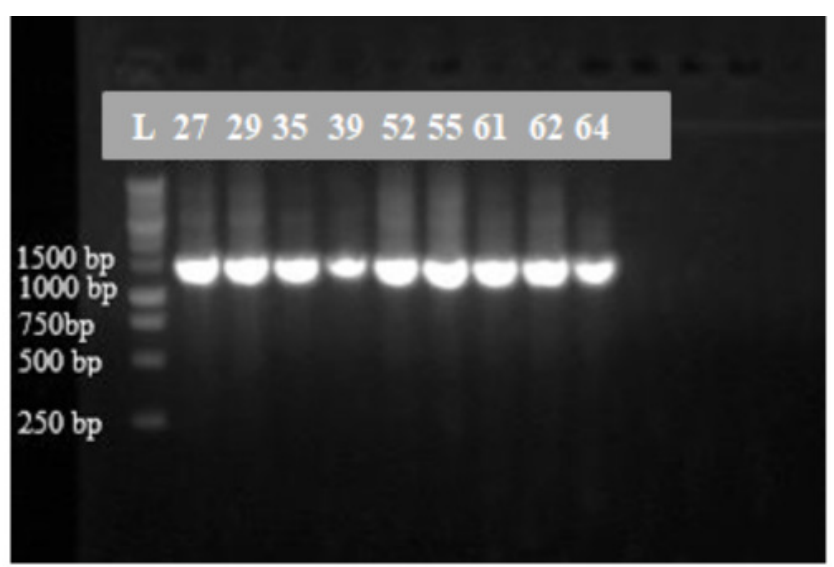

B.

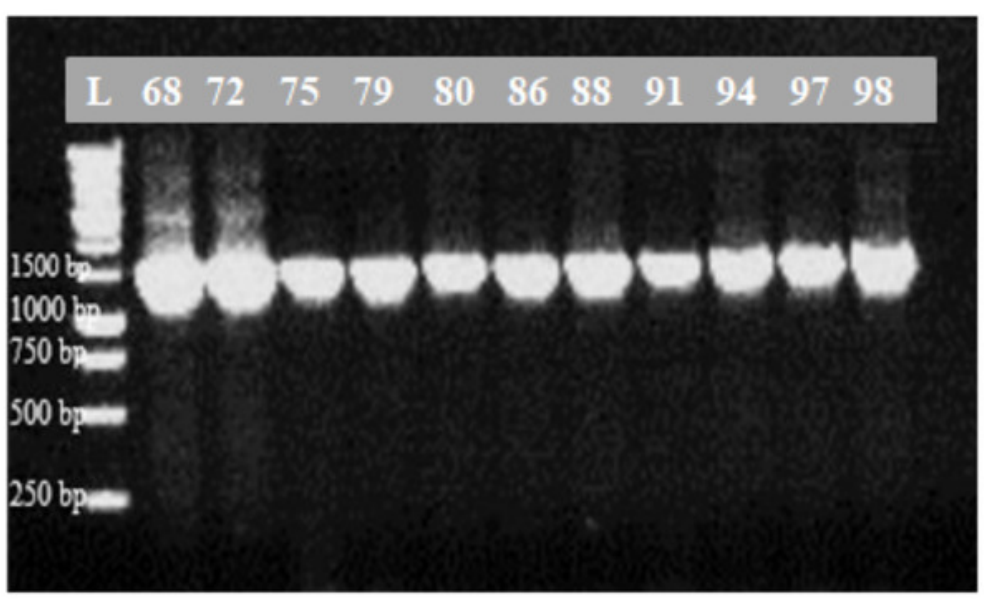

C. 
Figure 3

Phylogenetic tree

Neighbor-joining phylogenetic tree constructed using MEGA $X$ based on 16S rRNA gene sequences showing the relationship between (A) Vibrio spp.; (B) other different gram negative and gram positive bacterial species. Taxa labeled with green circles indicate the bacterial strains isolated from four types of samples collected from eight different shrimp nurseries in the present study. Other taxa were obtained from the NCBI database. 

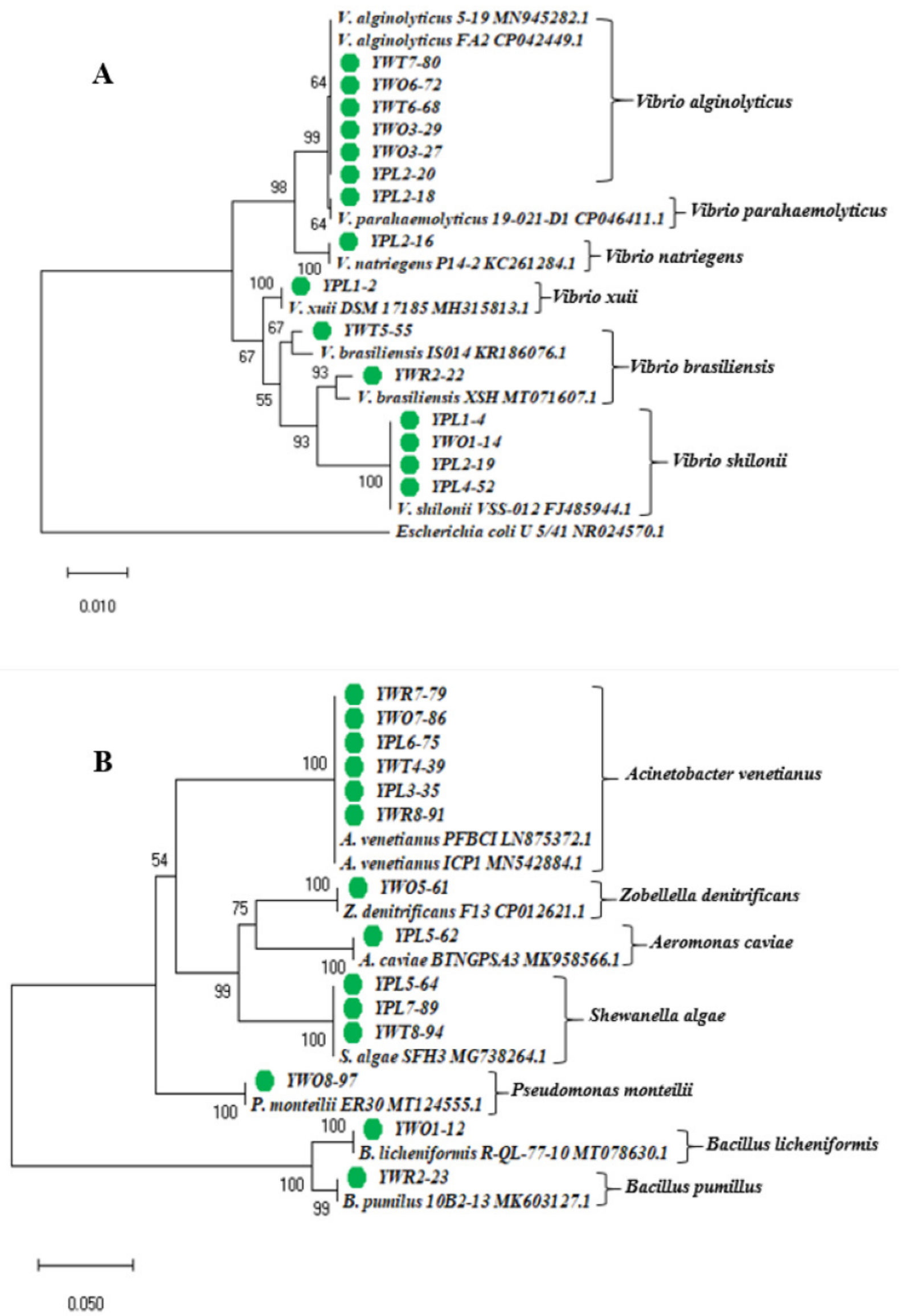
Figure 4

Antibiotic susceptibility of bacterial isolates

Percentage of antibiotic susceptibility of representative thirty bacterial isolates in $100 \%$ stacked column against 12 antimicrobial agents (Sul-Trimethoprim denotes

Sulphamethoxazole-Trimethoprim). 


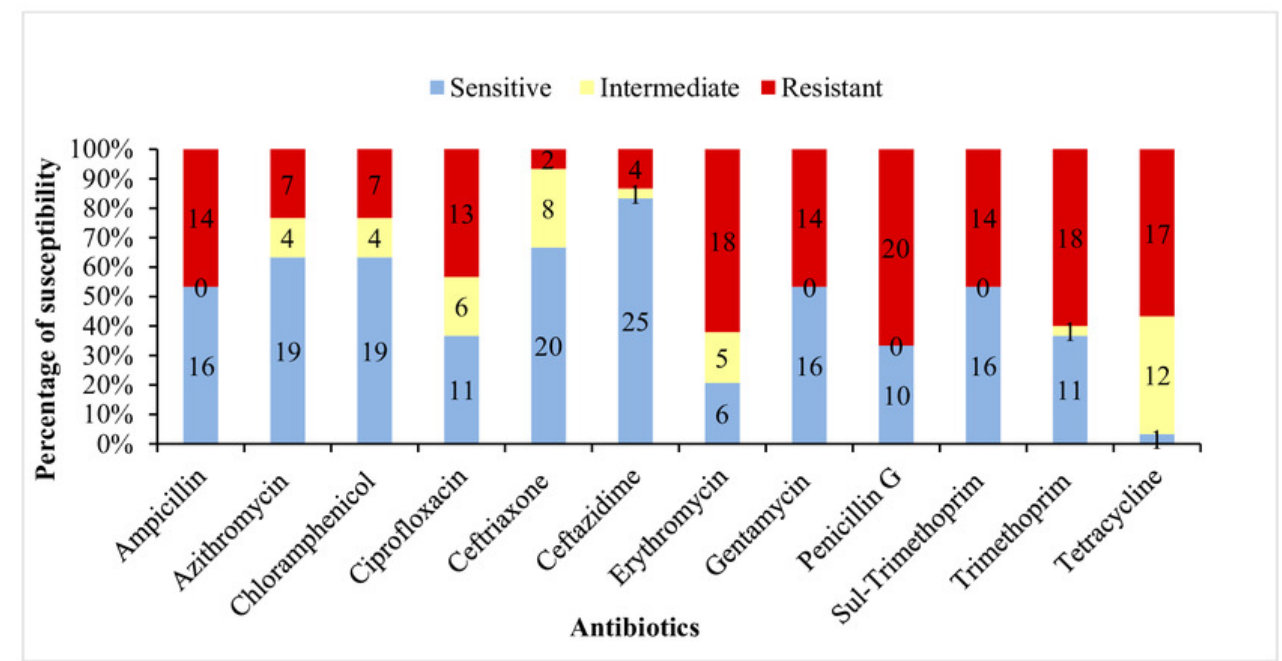


Figure 5

Antibiotic resistance pattern

Antibiotic resistance pattern against 12 antimicrobial agents of six studied isolates identified as Acinetobacter venetianus. 


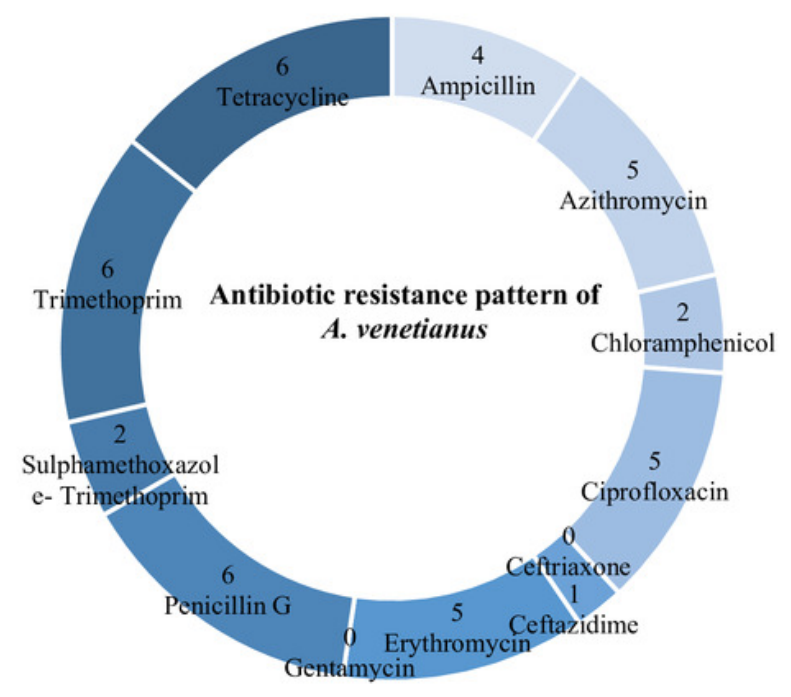


Figure 6

MAR index

MAR index values of 30 diversified studied bacterial isolates against 12 antimicrobial agents.

Red disconnected line with value (0.2) indicate maximum threshold value of MAR index for a bacterial isolate to be multiple antibiotic resistant. 


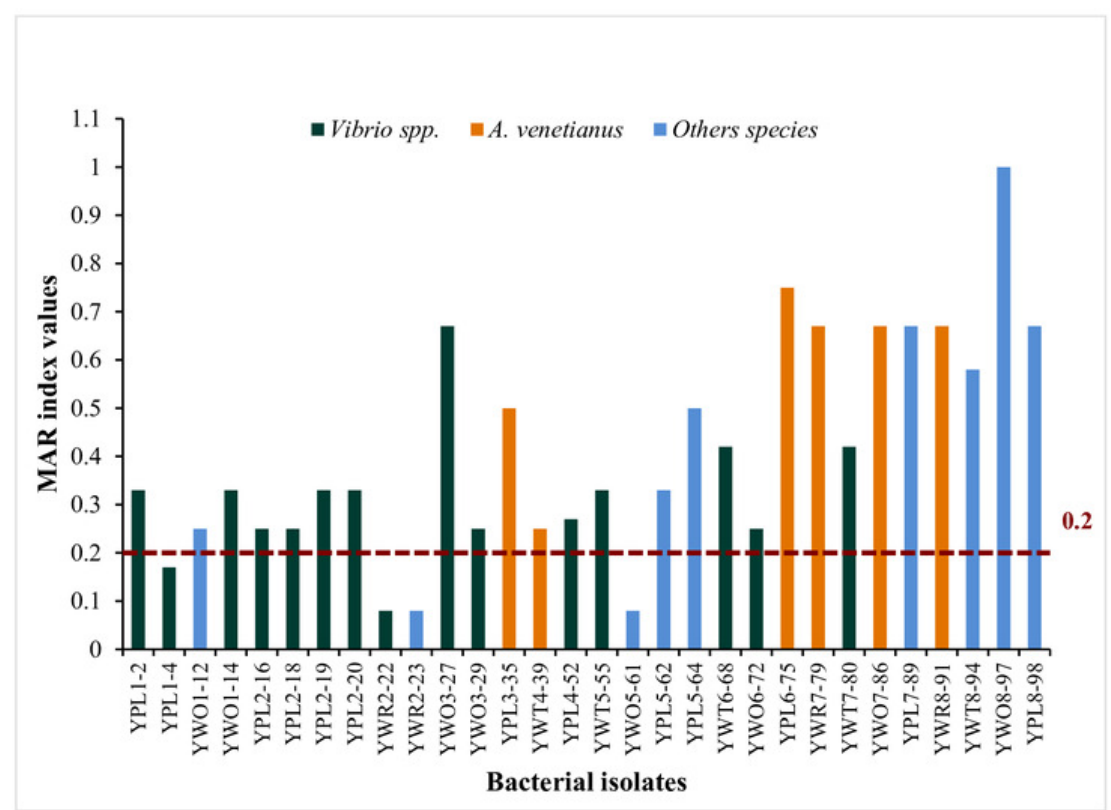

